\title{
RETROSPECTIVE ANALYSIS OF MALIGNANT EYELID TUMOURS IN A TERTIARY CARE CENTRE- 10 YEARS SURVEY
}

Hemalatha Krishnamurthy¹, Shashidhar H. B2, Satish K3, Manjula Devi N4, Jayashree Krishnamurthy5, Mohammed Abdul Kayoom N6, Gajaraj Nayak7, Reshma Angadi ${ }^{8}$

\author{
${ }_{1}^{1}$ Associate Professor, Department of Ophthalmology, MMC \& RI, Mysore. \\ ${ }^{2}$ Professor, Department of Pathology, MMC \& RI, Mysore. \\ 3 Professor and HOD, Department of Ophthalmology, MMC \& RI, Mysore. \\ ${ }^{4}$ Associate Professor, Department of Ophthalmology, MMC \& RI, Mysore. \\ 5 Professor and HOD, Department of Pathology, JSS Medical College, Mysore. \\ ${ }^{6} J$ unior Resident, Department of Ophthalmology, MMC \& RI, Mysore. \\ 7 Junior Resident, Department of Ophthalmology, MMC \& RI, Mysore. \\ 8Junior Resident, Department of Ophthalmology, MMC \& RI, Mysore.
}

\section{BACKGROUND}

\section{ABSTRACT}

Eyelid tumours are by far the most common neoplasms encountered in ophthalmic clinical practice and are estimated to represent more than $90 \%$ of all ophthalmic tumours.

The aim of the study is to evaluate and characterise the proportion of malignant eyelid tumours, compare the clinical diagnosis with histopathological diagnosis in all possible cases at a tertiary care centre over a 10-year period.

\section{MATERIALS AND METHODS}

This was a retrospective, clinical review. Between June 2006 and June 2016 all malignant eyelid tumours were evaluated in the Department of Ophthalmology, K. R. Hospital, MMC \& RI, Mysore. Patients' charts were reviewed for clinical information, treatment procedure, and pathological findings. Malignant tumours were stratified using age, sex, location of tumour and histopathological typing.

\section{RESULTS}

A total of 36 malignant tumours of the eyelid treated and histopathologically confirmed at our tertiary care centre were analysed. The peak incidence in this series was in patients 50-70 years of age. The mean age of patients with malignant tumours was above 61.5 (63 median age). Almost equal sex involvement noted, 19 men (52.77\%) and 17 women (47.22\%). But male preponderance was noted in SCC (88.89\%) and SGC was noted to be predominant in females (69.23\%). Most common site for malignancy was lower lid (61.11\%). Most frequent malignant tumours noted was Sebaceous gland carcinoma (SGC) (36.11\%) followed by Squamous cell carcinoma (SCC) (25\%), Basal cell carcinoma (BCC) (22.22\%), Malignant melanoma (MM) (8.33\%), Malignant Lymphoma (5.56\%) and Merkel cell carcinoma (MCC) (2.78\%).

\section{CONCLUSION}

SGC is the most common malignant lesion in our series. We stress the importance of examining specimens for histopathology, to ensure a rapid diagnosis and pertinent treatment.

\section{KEYWORDS}

Eyelid, Histopathology, Malignant, Merkel Cell Carcinoma, Sebaceous Gland Carcinoma.

HOW TO CITE THIS ARTICLE: Krishnamurthy H, Shashidhar HB, Satish K, et al. Retrospective analysis of malignant eyelid tumours in a tertiary care centre- 10 years survey. J. Evolution Med. Dent. Sci. 2018;7(06):708-713, DOI: $10.14260 /$ jemds/2018/161

\section{BACKGROUND}

Eyelid tumours are by far the most common neoplasms encountered in ophthalmic clinical practice and are estimated to represent more than $90 \%$ of all ophthalmic tumours.[1] Early detection of Eyelid malignancies are rarely lethal while invasive surgeries are needed for advanced tumours and have consequently adverse aesthetic effects.[2] Several studies

'Financial or Other Competing Interest': None.

Submission 26-09-2017, Peer Review 24-11-2017,

Acceptance 01-12-2017, Published 05-02-2018.

Corresponding Author:

Dr. Shashidhar H. B,

Flat No. 211, Second Floor,

D. S. Max Smaran Apartment,

Industrial Suburb, 3Rd Stage,

Vishweshwar Nagar, Mysore-570008.

E-mail: dr.hemalatha_k@yahoo.com

DOI: $10.14260 /$ jemds $/ 2018 / 161$ have investigated the incidence, age, risk factors, and clinical manifestations of eyelid tumours.[1-5] The benign eyelid tumours, outnumber the malignant eyelid lesions.[3-5] Clinical diagnosis and histopathological correlation have been studied in published case reviews. ${ }^{[2-8]}$ Eyelid tumours have been extensively reviewed in white patients, but the results do not concord to our observations in the Indian population. Basal cell carcinoma is the most common malignant eyelid tumour in whites. ${ }^{[4]}$ Among the malignant category, basal cell carcinoma(BCC) has been shown to have the highest incidence of the eyelid tumours followed by sebaceous gland carcinoma (SGC), lymphoma, squamous cell carcinoma(SCC), and malignant melanoma(MM).[8] However, the frequency of SGC is higher in Asian countries. [9-17]

This study intends to highlight the clinical and pathological profile of different malignant eyelid tumours in a tertiary care centre. 


\section{MATERIALS AND METHODS}

Material- The present study is a retrospective analysis of 36 consecutive cases of eyelid malignancies that reported to a tertiary health care centre at the Department of Ophthalmology, K. R. Hospital, Mysore Medical College and Research Institute, Mysore, Karnataka, South India over a 10year period starting from 15th June 2006 to $15^{\text {th }}$ June 2016. Thirty-six cases with histopathologically confirmed malignant eyelid tumours were retrieved through a detailed retrospective review of records.

Methods- Data were recorded for each patient including demographic and general information, exact anatomic location of lesion, time of presentation, treatment procedure and disease course. Follow-up data included length of followup, incidence of tumour recurrence, time between treatment and recurrence, and management of recurrence. Ethical committee clearance was obtained from our institute.

\section{RESULTS}

A total of 36 malignant tumours of the eyelid treated at our tertiary care centre during the 10 -year period from $15^{\text {th }}$ June 2006 to $15^{\text {th }}$ June 2016 were analysed. The peak incidence in this series was in patients 50-70 years of age. A slight male preponderance noted with female $(47.22 \%)$ and male (52.77\%). Most common site for malignancy was lower lid (61.11\%). Sebaceous gland carcinoma [SGC] was the most common lesion frequently seen. Sebaceous gland carcinomas were detected in 13 cases (36.11\%), followed by 9 cases (25\%) of squamous cell carcinoma, 8 cases $(22.22 \%)$ of basal cell carcinoma, malignant melanoma [MM] 3 cases $(8.33 \%)$, malignant lymphoma 2 cases (5.56\%) and Merkel cell carcinoma [MCC] in 1 case (2.78\%). Graph 1 shows the incidence of various malignant eyelid tumours in our study. Fig.1 shows the common malignant eyelid tumours. Fig.2 shows rare malignant eyelid tumours.

In 11 cases of sebaceous adenocarcinomas, tumour was in the upper eyelid and 2 cases had it in lower lid. 7 cases had basal cell carcinomas in the lower eyelid and 1 in upper lid. Squamous cell carcinomas were 2 in the upper lid and 7 in lower eyelid. Table 1 shows demographic features of various malignant eyelid tumours. The most common presenting complaint was mass with ulceration across all histological types. 5 patients of BCC (13.89\%), 10 patients of SGC $(27.78 \%)$ and 6 patients of SCC (16.67\%) presented with mass and overlying ulceration. Mass alone was the presenting complaint in 3 patients of BCC, SGC, SCC, MM, 2 cases of lymphoma and 1 case of MCC. Other associated complaints included redness, discharge from eye, pain and ptosis. Three patients of SGC had history of recurrent chalazion. MCC patient presented with a painless swelling over the left lower eyelid.

The follow-up of cases ranged from 1 to 60 months (mean=24 months). Follow-up information was obtained on 26 of the 36 cases. There was one recurrence of basal cell carcinoma. In two cases one with MCC and another case of SGC had the regional lymph nodes involvement at the time of presentation. Most malignant eyelid tumours were managed by wide surgical excision of the lesion large enough to obtain tumour-free margins and confirmed by histopathological examination. Lid reconstruction was done wherever required. Eyelid reconstructive technique included various procedures like direct closure for defects measuring less than $25 \%$, direct closure with lateral canthotomy and cantholysis for defects measuring slightly larger than $25 \%$, Tenzel semicircular rotational flap for defects up to $2 / 3^{\text {rd }}$ of upper or lower lid width. Lid-sharing procedure was done when the defect was too large, Hughes flap technique for lower eyelid defect or Cutler-Beard technique for upper eyelid defect was done. In case of MCC, fine needle aspiration and cytology (FNAC), histopathology study and immunohistochemical (IHC) findings of the swelling and the preauricular lymph node were diagnostic of MCC with regional metastasis. Current therapeutic regimen included wide local excision, regional lymphadenectomy with adjuvant radiotherapy.

Postoperatively, all were taken up successfully. There were only few common postoperative complaints- itching, foreign body sensation and conjunctival congestion. Followup of patients reported, itching at the graft site in 10 patients which regressed after use of oral antihistamines and topical antibiotic. Although most of the cases were treated with surgical excision, some were treated with external radiotherapy and/or chemotherapy for which they were referred to higher centre.

\begin{tabular}{|c|c|c|c|c|c|c|c|}
\hline 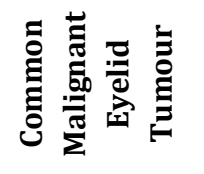 & 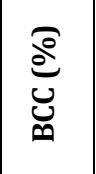 & 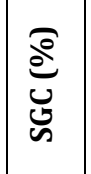 & 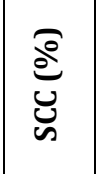 & $\sum_{\sum}^{\mathfrak{d}}$ & 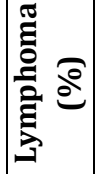 & 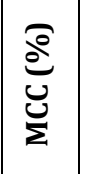 & 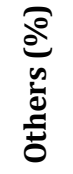 \\
\hline $\begin{array}{c}\text { Present study } \\
n=36\end{array}$ & 22.22 & 36.11 & 25.00 & 8.33 & 5.56 & 2.78 & \\
\hline $\begin{array}{c}\text { Abdi et al } \\
\text { (India) } n=85\end{array}$ & 38.8 & 27.1 & 22.4 & 3.5 & & & 8.2 \\
\hline $\begin{array}{l}\text { Sihota et al } \\
\text { (India) }\end{array}$ & 29.8 & 32.6 & 28.1 & 2 & & & 7.5 \\
\hline $\begin{array}{c}\text { Lee et al } \\
\text { (Singapore) }\end{array}$ & 84 & 10.2 & 3.4 & 1.2 & & & \\
\hline $\begin{array}{c}\text { Abe M et al } \\
\text { (Japan) }\end{array}$ & 32.69 & 13.46 & 48.1 & 3.85 & 1.92 & & \\
\hline $\begin{array}{l}\text { Pornpanich } \\
\text { et al } \\
\text { (Thailand) } \\
n=32\end{array}$ & 40.62 & 37.5 & 6.25 & 9.38 & & & 6.25 \\
\hline $\begin{array}{l}\text { Obata H et al } \\
\text { (Japan)n=24 }\end{array}$ & 37.5 & 37.5 & & 2 & 16.6 & & 8.3 \\
\hline $\begin{array}{c}\text { Wang JK et al } \\
\text { (Taiwan) }\end{array}$ & 62.2 & 23.6 & 8.7 & 3.9 & & & 1.6 \\
\hline $\begin{array}{c}\text { Lin et al } \\
\text { (Taiwan) } \\
\mathrm{N}=1166\end{array}$ & 65.1 & 7.9 & 12.6 & 2 & & & 8.3 \\
\hline $\begin{array}{c}\text { Xu Xl et al } \\
\text { (Beijing) } \\
\mathrm{N}=2639\end{array}$ & 41 & 39 & 5 & 4 & 9 & & \\
\hline \multicolumn{8}{|c|}{$\begin{array}{c}\text { Table 1A. Common Malignant Eyelid Tumours Reported } \\
\text { from Various Asian Countries. SGC is more Common in } \\
\text { Asian Population Accounting for 27-40\% of all Eyelids } \\
\text { Malignancies }\end{array}$} \\
\hline
\end{tabular}




\begin{tabular}{|c|c|c|c|c|c|}
\hline $\begin{array}{l}\text { Author, Country, } \\
\text { n=no. of } \\
\text { Malignant } \\
\text { Cases }\end{array}$ & BCC & SGC & SCC & MM & Lymphoma \\
\hline $\begin{array}{l}\text { Cook BE et al, } \\
\text { Minnesota, } \\
n=174\end{array}$ & 90.8 & & 8.6 & 0.6 & \\
\hline $\begin{array}{c}\text { Ni et al, U.S, } \\
n=1543\end{array}$ & 92.5 & 1.5 & 4.6 & 1.1 & \\
\hline $\begin{array}{l}\text { Deprez et al, } \\
\text { Switzerland, } \\
\text { n=880 }\end{array}$ & 86 & 3 & 7 & & \\
\hline $\begin{array}{c}\text { Paul et al, San } \\
\text { Francisco, } n=206\end{array}$ & 71.8 & 7.3 & 9.7 & 9.2 & \\
\hline $\begin{array}{c}\text { Weiner et al, } \\
\text { Australia, } \mathrm{n}=473\end{array}$ & 88.8 & 3.8 & 7.4 & & \\
\hline $\begin{array}{l}\text { Bagheri et al, } \\
\text { Tehran, } n=100\end{array}$ & 83 & 6 & 8 & & \\
\hline \multicolumn{6}{|c|}{$\begin{array}{l}\text { Table 1B. Common Malignant Tumours Reported from } \\
\text { Western Countries and from Tehran. BCC is the } \\
\text { Commonest Malignant Tumour Reported from Western } \\
\text { Countries }\end{array}$} \\
\hline
\end{tabular}

\begin{tabular}{|c|c|c|c|c|c|c|}
\hline 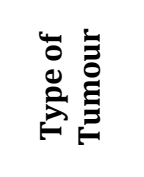 & U్ & U્ & U্ & 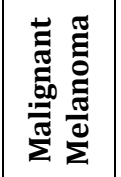 & & U્ \\
\hline $\begin{array}{c}\text { Upper lid } \\
(\%)\end{array}$ & $\begin{array}{c}11 \\
(84.62)\end{array}$ & $\begin{array}{c}1 \\
(12.5)\end{array}$ & $\begin{array}{c}2 \\
(25)\end{array}$ & $\begin{array}{c}0 \\
(0)\end{array}$ & $\begin{array}{c}0 \\
(0)\end{array}$ & $0(0)$ \\
\hline $\begin{array}{c}\text { Lower lid } \\
(\%)\end{array}$ & $\begin{array}{c}2 \\
(18.18)\end{array}$ & $\begin{array}{c}7 \\
(87.5)\end{array}$ & $\begin{array}{c}7 \\
(77.78)\end{array}$ & $\begin{array}{c}3 \\
(100)\end{array}$ & $\begin{array}{c}2 \\
(100)\end{array}$ & $1(50)$ \\
\hline $\begin{array}{c}\text { Combined } \\
(\%)\end{array}$ & $0(0)$ & $0(0)$ & $0(0)$ & $0(0)$ & $0(0)$ & $1(50)$ \\
\hline $\begin{array}{c}\text { Right Eye } \\
(\%)\end{array}$ & $\begin{array}{c}10 \\
(76.92)\end{array}$ & $\begin{array}{c}6 \\
(75)\end{array}$ & $\begin{array}{c}6 \\
(66.67)\end{array}$ & $\begin{array}{c}1 \\
(33.33)\end{array}$ & $\begin{array}{c}1 \\
(50)\end{array}$ & $0(0)$ \\
\hline $\begin{array}{c}\text { Left Eye } \\
(\%)\end{array}$ & $3(23.08)$ & $2(25)$ & $\mid \begin{array}{c}3 \\
(33.33)\end{array}$ & $\mid \begin{array}{c}2 \\
(66.67)\end{array}$ & $1(50)$ & $1(100)$ \\
\hline \multicolumn{7}{|c|}{ Table 2. Location of Malignant Tumours } \\
\hline
\end{tabular}

The lower lid (61.11\%) was the most common location of malignant tumours, exception being SGC wherein $84.62 \%$ of cases involved the upper lid, MCC had combined involvement of Left lower lid and medial canthus.

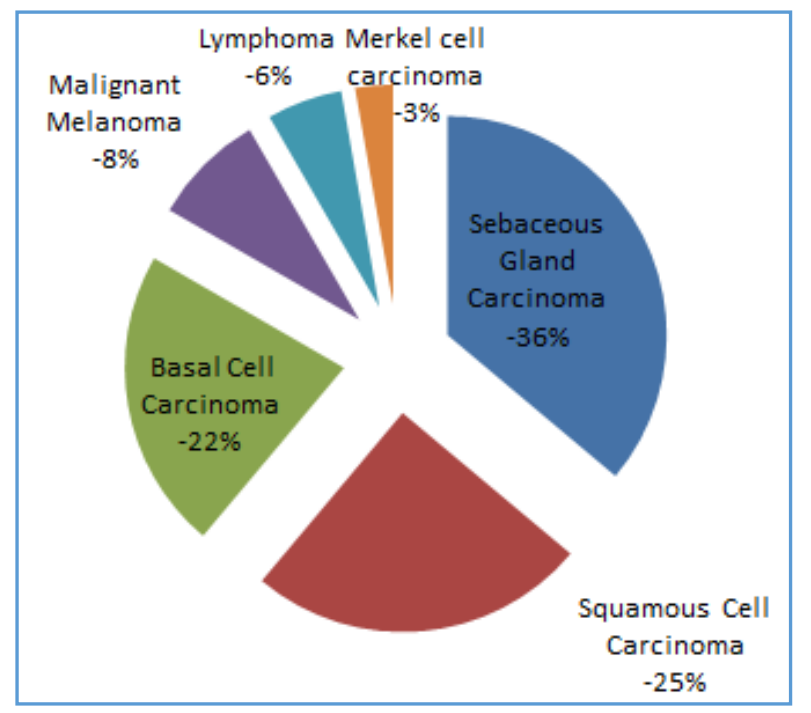

Graph 1. Various Malignant Eyelid Tumours in our Study

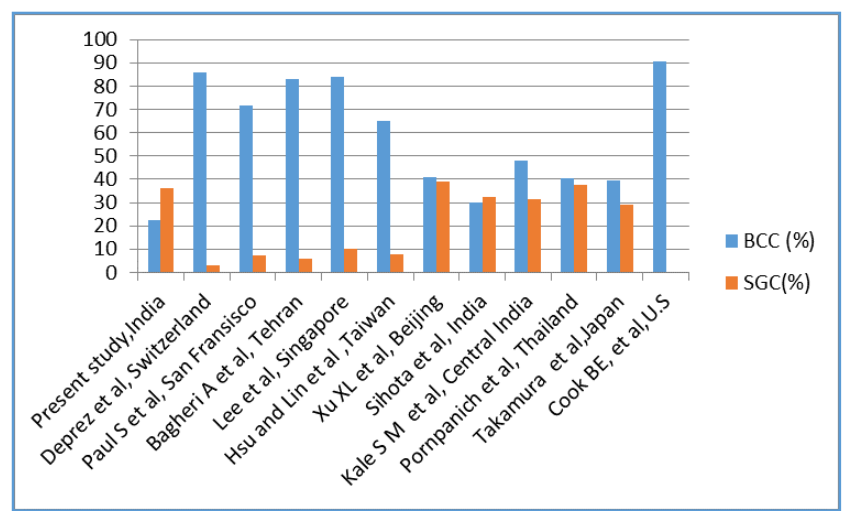

Graph 2. Comparison of Incidence of BCC and SGC showing Increased Incidence of BCC in Western Countries and Increased Incidence of SGC in Asian Countries

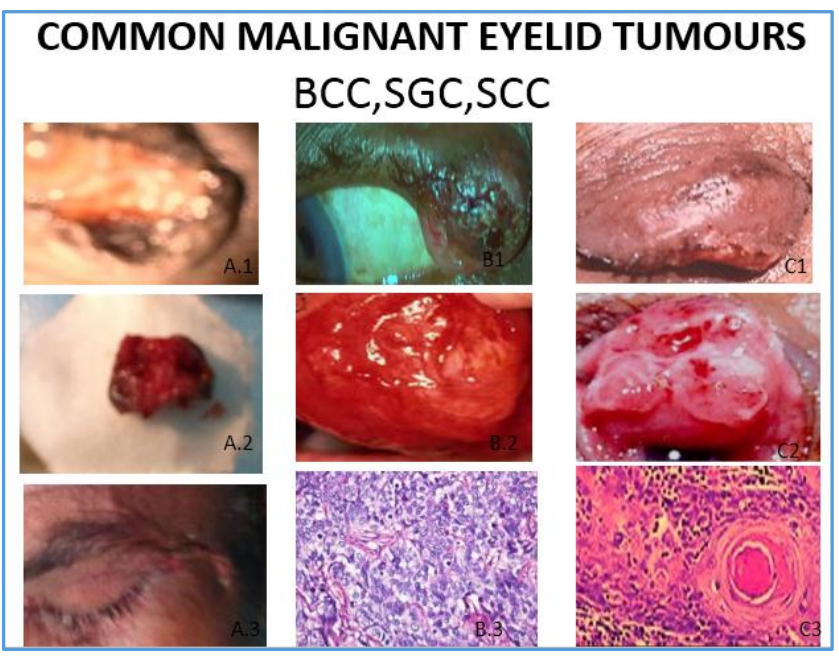

COMMON MALIGNANT EYELID TUMOURS BCC, SGC, SCC

- A.1-BCC- Nodule with central ulceration, raised rolled edges in left lower eyelid.

- A.2-Excised growth.

- A.3 - BCC case Post lid reconstruction surgery.

- $\quad$ B.1. SGC-Nodule over left upper eyelid.

- B.2 Nodule with ulceration seen from conjunctival side SGC.

- $\quad$ B.2. SGC -Histopathological features- Cells Composed of foamy multivacuolated cytoplasm and hyperchromatic nuclei.

- $\quad$ C.1-SCC-Nodule with ulceration over left upper lid.

- C.2- Nodule with large ulcer.

- C.3.-Variable sized atypical epithelial cells in groups within the dermis. Prominent nuclei and abundant acidophilic cytoplasm. Amidst seen keratin pearl. 


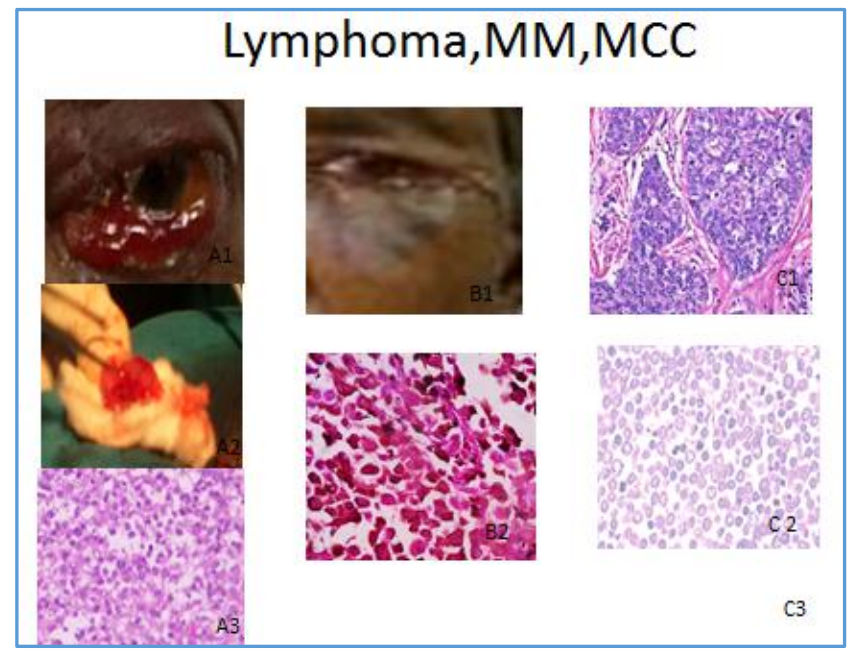

\section{RARE MALIGNANT EYELID TUMOURS}

Lymphoma, MM, MCC

- A1- Hard tender nodular swelling with overlying chemosis in left lower lid.

- A2- Excised nodule.

- A3- Oval-to-round large tumour cells with vesicular nucleus, cytoplasm is pale pink arranged in nest, sheet pattern, amidst interspersed spider cells are seen.

- $\quad$ B1- Malignant melanoma - tumour excision done with lid reconstruction, Postoperative picture.

- B2- Composed of oval-to-round epithelioid cells with varying amounts of melanin pigment.

- $\quad$ C1 MCC-HPR: Composed of small, round uniform cells arranged in lobules, nests, trabecular, sheets pattern with scanty cytoplasm, nucleus being round with mitotic figures and dispersed chromatin.

- $\quad$ C2 - Immunohistocytometry- Positive for cytokeratin 20 Dot-like immunoreactivity.

\section{DISCUSSION}

From the retrospective data collected from our hospital records, the clinicopathological profile of 36 cases of malignant eyelid tumours were reviewed. The prevalence of different types of eyelid tumours is influenced by Geographical region, latitude, people protecting themselves from sunlight and Ultraviolet exposure, ethnicity and Genetic factors, [2]

The malignant tumours present differently, their progression varies and response to surgery differs in each case.[18] Malignancies requiring wide margin resection often pose challenging reconstructive problems to the treating surgeon.[11]

The three most common malignant tumours in our study were SGC (36.11\%), SCC (25\%), and BCC (22.22\%) which concords with an Indian study by Sihota et al, they report sebaceous adenocarcinoma (32.6\%), BCC (29.8\%), and SCC (28.1\%),[9] supported by another Indian study where they report $38.8 \%$ of BCC, $27.1 \%$ of SGC, and $22.4 \%$ of SCC.[6] Studies from various countries have reported different types and frequencies of malignant eyelid tumours, some of these reports have been listed in Table $2 \mathrm{~A}$ which shows common malignant eyelid tumours from various Asian countries, and Table 2B shows common malignant eyelid tumours from western countries.[2-22]

In the present study, the mean age of patients with malignant tumours was above 61.5 (63 median age). This finding is in agreement with most of the studies by Wang J K et al (62.6 years median age),[14] A Bagheri et al (mean age $>60$ years) as well as the study by Vitaliano and Urbach et al who consider age an important risk factor in non-melanoma skin tumours.[2] The median age of presentation was 58 years for SGC, 60 years for BCC, 62 years for SCC, 56.6 years for melanoma, 70 years for lymphoma and MCC presented at 52 years in our study. Studies from Singapore reported median age 63 years in males and 66 years in females. [17] Lin Hsin-Yi et al reported that the mean age at diagnosis of eyelid cancers was $62.6 \pm 14.1$ years in Taiwan. ${ }^{[20]}$ Fonthip Na Pombejara et al reported a rather earlier mean age of presentation [52.4 years [SD 21.8)] in Thailand.[22] A slightly later age of presentation of $72.0 \pm 12.4$ years has been reported by Takamura Hiroshi from Japan.[15]

BCC is the most common eyelid malignant tumour worldwide. $[2,4,5,8,11]$ The common malignancy in white population is Basal cell carcinoma.[1] Worldwide incidence of BCC is increasing by up to $10 \%$ a year. Approximately, BCC may develop in 3 among 10 Caucasians within their lifetime.[16] Studies by Paul S et al, Deprez et al, Cook BE Jr et al reported $71.8 \%, 86 \%$ and $90.8 \%$ BCC respectively, which was the most common malignant tumour in their case series.[3-5] However, Asian countries have consistently reported a relatively lower incidence of BCC. Wang et al reported an incidence of $62.2 \%$ in study done in Taiwan. ${ }^{[14]}$ Another study by Lin Hsin-Yi et al from Taiwan, reported BCC as the most common eyelid malignancy, but it accounted for only $65.1 \%[20]$ and BCC constitutes $64 \%$ of all eyelid tumours in Thailand.[22] Lee S B et al in Singapore have reported 84\% incidence of $\mathrm{BCC},[17]$ this is the only exception to this lower trend of BCC incidence in Asian countries. Incidence of BCC reports from central India: Sihota et al reported 30\%, Jahagirdar S S et al reported $44.5 \%$ and Kale SM et al reported $48.2 \%,{ }^{[9,10,11]}$ all show a much lower incidence comparatively. In the present study, BCC accounted $22.22 \%$ of all malignancies which is less than the incidence reported by other Asian countries and is significantly lower than that reported by the western countries. This may be due to small series of cases studied.

Among BCC cases equal sex incidence was noted, and this tumour also showed a preference for the lower eyelid in the present study, as also reported by Paul S et al and Wang C J et al.[3,16] In general, $20 \%$ of BCC occur in the periocular area of which half of the cases present in the lower eyelid, $15 \%$ in the upper eyelid, one-third in the medial canthus and 5\% in the lateral canthus. [2]

The longest period between the disease symptoms and referral to our centre was that of BCC (30 months) and the shortest period was related to lymphoma (1.5 months). Same as in our study series, Takamura et al[15] have reported that BCC had the longest time between the onset of the disease and referral (40 months) followed by SGC (11 months), SCC (10 months) and finally lymphoma (1 month).[2] In the early stages, BCC patient is very asymptomatic and it progresses very slowly. So in any eyelid tumour, a prompt biopsy is highly recommended which helps in early detection of malignant tumours.[2] 
In our study, with 5 years follow-up of patients, there was 1 recurrent case of BCC in an elderly male aged 85 years after 10 months of initial surgery who had relatively large tumour measuring $1.6 \mathrm{~cm}$. The recurrence rate for this BCC tumour in the eyelid was $12.5 \%$ in our study and it concords with the study by Wang $\mathrm{C} J$ et al, they have reported $(11.4 \%)$ as recurrence rate of $\mathrm{BCC}$ and 74 months as mean time of recurrence. Reports from Wang states that the mean time to recurrence or metastasis after primary treatment was longer for BCC than for SGC (47 months), SCC (30 months), or MM (22 months).[16] Looking for recurrence, BCC patients should be followed up for a longer period.

In white population, SGC is very rare accounting for 1$5.5 \%$ of all eyelid malignancies.[11,14,23] SGC was the most common malignant tumour and accounted for $36.11 \%$ of all malignant eyelid tumour cases in this present study. Our study concords with study done by Kale S M et al where they report SGC incidence $31.4 \%$ in their series and another study by $\mathrm{Ni}$ et al (U S) reported that SGC accounted for 32.7\% of malignant eyelid tumours in Shanghai. Whereas, at the Massachusetts Eye and Ear Institute in United States, SGC accounted for only $1.5 \%$ of malignant eyelid tumours.[11,19] Genetic and racial predisposition may probably play an important aetiological role.[16]

SGC is more common in Asian population accounting for $27-40 \%$ of all eyelid malignancies.[14,15,23] Study reports from India, Japan, China and Thailand provide evidence, in favour of a higher proportion (30-40\%) of occurrence of SGC. $[9,10,11,12,15,16,22]$ Graph 2: Comparison of incidence of SGC and BCC showing increased incidence of SGC in Asian countries and increased incidence of BCC in western countries.

Studies by Wang $\mathrm{J} \mathrm{K}$ et al and Wang $\mathrm{C} \mathrm{J}$ et al have reported SGC incidence of 8-29\%.[14,16] SGC was reported in only $7.3 \%$ of all eyelid malignancies in the San Francisco population than other parts of the United States, despite having a significantly higher no. of Asians. Recent study by Dasgupta et al has confirmed that established Asian/Pacific Islander ancestry is not a risk factor for developing sebaceous carcinoma.[3,24] SGC is known to masquerade as chalazion in eyelid lesions, so the possibility of SGC should be considered in Asians presenting with persistent or recurrent chalazion.[23]

In the present study, equal sex predilection was noted in BCC and a male preponderance was noted in SCC (88.89\%). However, SGC was noted to be predominant in females (69.23\%). Various studies report large variations in the sex ratio. Equal sex distribution was reported by Sihota et al for both SGC and BCC, but males were relatively often affected with SCC $(60 \%)$ and our study concords with this study. ${ }^{[9]}$ Wang $\mathrm{J} \mathrm{K}$ et al reported that the incidence of eyelid malignancies more in women than men $(54.3 \%$ vs. $45.7 \%)$, female outnumbered men in SGC ( 21 females, 9 males) but male predominance was noted in BCC (43 males, 36 females).[14] The sex incidence variation is possibly due to variations in the cohort of patients under study series.

The lower eyelid was the most common location of all malignant tumours in this study and accounted for $61.11 \%$, this concords with other previous studies. $[2,12,19,24]$ Exception being patients with SGC showed very strong preference for upper eyelid (84.62\%). Except SGC the lower eyelid was also the most common site for all histological subtypes. Incidence of SGC is reported more commonly in the upper eyelid than the lower.[11, 14] Relatively greater number of meibomian glands located in the upper lid (30) versus the lower lid (20) makes this preference possible.[3] High preference of the upper lid in SGC cases concords with various study reports.[11,23] Lid lesions particularly of the upper eyelid, are warranted in older patients, as it is commonly misdiagnosed for chronic blepharoconjunctivitis, chalazion and meibomitislike inflammatory lesions resulting in delayed diagnosis so needs early consultation and histopathological diagnosis of such lid lesions. [4] As observed in present study, the predominance of BCC in the lower lid (87.5\%) has been reported in many studies.[14,16]

The second most common tumour was squamous cell carcinoma (SCC) accounting for $25 \%$ of malignancies examined. In this study, a preference for the lower lid $(66.67 \%)$ and a male preponderance $(88.89 \%)$ was noted in SCC cases which is similar to the studies by Sihota et al.[9] Abe et al in their study, have reported SCC (48.1\%) to be the most common eyelid cancer, followed by BCC (32.6\%) and SGC $(13.5 \%){ }^{[12]}$ The prevalence of SCC reported from various studies in India is $14-28 \%[9,10,11]$ and our study concords with their reports.

Other malignant tumours noted in this study included malignant melanoma 3 cases (8.33\%), malignant lymphoma 2 cases (5.56\%) and Merkel cell carcinoma in 1 case $(2.78 \%)$. On diagnosis of squamous cell carcinoma, lymphoma and malignant melanoma a thorough systemic evaluation for regional or distant metastasis is always necessary and must.[16]

The number of cases of malignant melanoma in present study were three $(8.33 \%)$ involving lower lid in all and one case had multiple lesions in lower lid. In the present study, the mean age of presentation was 58 years and median age 56.6 years for MM and a female preponderance $(100 \%)$ was observed similar to other studies Sunderraj $\mathrm{P}$ et al and Ratnakar et al.[25,26] Our study report of MM 8.33\% concords with study done in Thailand by Pornpanich who reports $9.3 \%$ $M M,{ }^{[22]}$ Study done by Wang $\mathrm{C} J$ et al who have reported MM, $13.3 \% .{ }^{[16]}$ Abe et al[12] from Japan reported MM 3.85\%, Abdi U et al[6] from India reports MM 3.5\%. A similar report of MM $3.9 \%$ by Wang JK et al[14] from Taiwan and MM $1.2 \%$ by Lee et al[17] from Singapore shows all are much lower than our study report except that of Wang which is higher and all these do not concord with our report.

Ocular adnexal Lymphomas account for (lymphomas of eyelids, lacrimal gland, lacrimal sac conjunctiva and orbit) $2 \%$ of extranodal lymphomas.[27] We encountered 2 cases of malignant lymphoma in our present study (5.56\%). Obata et al[28] has reported 4 cases $(16.6 \%)$ of malignant lymphoma, this does not concord whereas Ade $M$ et al[12] from Japan reported $1.92 \%$ which is also much lower and does not concord with our study. This may be due to small case series in the present study.

Merkel cell carcinoma (MCC) is one of the rare and aggressive neuroendocrine skin malignancy that occasionally affects the eyelid, with the potential for significant incidence of local recurrence, regional and distant metastasis.[16, 29] We encountered a single case of MCC in our present study accounting for $2.78 \%$. Wang $\mathrm{C}$ J et al have reported 1 Merkel cell carcinoma (MCC, 1.3\%) in their study.[16] 


\section{CONCLUSION}

High rate of occurrence of SGC is uniquely evident from studies in India, requiring a high index of suspicion and aggressive treatment. We wish to stress the importance of examining specimens histopathologically, to ensure a rapid diagnosis and pertinent treatment. It's essential for early referral and diagnosis for adequate functional and cosmetic lid reconstruction.

\section{REFERENCES}

[1] Kleinstein RN, Lehman HF. Incidence and prevalence of eye cancer. Am J Optom Physiol Optics 1977;54(1):49-51.

[2] Bagheri A, Tavakoli M, Kanaani A, et al. Eyelid Masses: a 10-year survey from a tertiary eye hospital in Tehran. Middle East African Journal of Ophthalmology 2013;20(3):187-92.

[3] Paul S, Vo Dat T, Silkis RZ, et al. Malignant and benign eyelid lesions in San Francisco: study of a diverse urban population. American Journal of Clinical Medicine 2011;8(1):40-6.

[4] Cook BE, Bartley GB. Epidemiologic characteristics and clinical course of patients with malignant eyelid tumors in an incidence cohort in Olmsted County, Minnesota. Ophthalmology 1999;106(4):746-50.

[5] Deprez M, Uffer S. Clinicopathological features of eyelid skin tumors. A retrospective study of 5,504 cases and review of literature. Am J Dermatopathol 2009;31(3):256-62.

[6] Abdi UN, Tyagi V, Maheshwari V, et al. Tumors of eyelid: a clinicopathological study. J Indian Med Assoc 1996;94(11):405-9, 416, 418.

[7] Chang $\mathrm{CH}$, Chang SM, Lai $\mathrm{YH}$, et al. Eyelid tumors in southern Taiwan: a 5-year survey from a medical university. Kaohsiung J Med Sci 2003;19(11):549-53.

[8] Xu XL, Li B, Sun XL, et al. Eyelid neoplasms in the Beijing Tongren Eye Centre between 1997 and 2006. Ophthalmic Surg Lasers Imaging 2008;39(5):367-72.

[9] Sihota RK, Tandon K, Betharia SM, et al. Malignant eyelid tumors in an Indian population. Arch Ophthalmol 1996;114(1):108-9.

[10] Sameer S Jahagirdar SS, Thakre TP, Kale SM, et al. A clinicopathological study of eyelid malignancies from central India. Indian J Opthalmol 2007;55(2):109-12.

[11] Kale SM, Patil SB, Khare N, et al. Clinicopathological analysis of eyelid malignancies - a review of 85 cases. Indian J Plast Surg 2012;45(1):22-8.

[12] Abe M, Ohnishi Y, Hara Y, et al. Malignant tumour of the eyelid: clinical survey during a 22-year period. Jpn J Ophthalmol 1983;27(1):175-84.

[13] Karan S, Nathani M, Khan T, et al. Clinicopathological study of eye lid tumours in Hyderabad - a review of 57 cases. J Med Allied Sci 2016;6(2):72-6.
[14] Wang JK, Liao SL, Jou JR, et al. Malignant eyelid tumours in Taiwan. Eye (Lond) 2003;17(2):216-20.

[15] Takamura H, Yamashita H. Clinicopathological analysis of malignant eyelid tumor cases at Yamagata university hospital: statistical comparison of tumor incidence in Japan and in other countries. Jpn J Ophthalmol 2005;49(5):349-54.

[16] Wang CJ, Zhang $\mathrm{HN}, \mathrm{Wu} \mathrm{H}$, et al. Clinicopathological features and prognostic factors of malignant eyelid tumors. Int J Ophthalmol 2013;6(4):442-7.

[17] Lee SB, Saw SM, Au Eong KG, et al. Incidence of eyelid cancers in Singapore from 1968 to $1995 . \mathrm{Br} \mathrm{J}$ Ophthalmol 1999;83(5):595-7.

[18] Weiner JM, Henderson PN, Roche J. Metastatic eyelid carcinoma. Am J Ophthalmol 1986;101(2):252-4.

[19] Ni C, Searl SS, Kuo PK, et al. Sebaceous cell carcinomas of the ocular adnexa. In: Ni C, Albert DM. eds. Tumours of the eyelid and orbit: a Chinese-American Collaborative Study. $2^{\text {nd }}$ edn. Boston: Little Brown 1982;22:23-61.

[20] Lin HY, Cheng CY, Hsu WM, et al. Incidence of eyelid cancers in Taiwan: a 21-year review. Ophthalmology 2006;113(11):2101-7.

[21] Cook BE, Bartley GB. Treatment options and future prospects for the management of eyelid malignancies: an evidence-based update. Ophthalmology 2001;108(11):2088-98.

[22] Pornpanich K, Chindasub P. Eyelid tumors in Siriraj hospital from 2000-2004. J Med Assoc Thai 2005;88(Suppl 9):S11-S4.

[23] Sagili S, Malhotra R. The importance of considering Sebaceous gland carcinoma in presumed chalazia in South Asian patients? Br J Gen Pract 2013;63(607):74.

[24] Dasgupta T, Wilson LD, Yu JB. A retrospective review of 1,349 cases of sebaceous carcinoma. Cancer 2009;115(1):158-65.

[25] Sunderraj P. Malignant tumours of the eye and adnexa. Indian J Ophthalmol 1991;39(1):6-8.

[26] Ratnakar C, Krishnan MM, Veliath AJ. Paper presented at the Annual Conference of the Madras State Ophthalmol Assoc. 1986.

[27] Rasmussen PK. Diffuse large b-cell lymphoma and mantle cell lymphoma of the ocular adnexal region and lymphoma of the lacrimal gland: an investigation of clinical and histopathological features. Acta Ophthalmologica Special Issue 2013;91(Issue thesis 5):1-27.

[28] Obata H, Aoki Y, Kubota S, et al. Incidence of benign and malignant lesions of eyelid and conjunctival tumors. Nippon Ganka Gakkai Zasshi 2005;109(9):573-9.

[29] Tarantola TI, Vallow LA, Halyard MY, et al. Prognostic factors in Merkel cell carcinoma: analysis of 240 cases. J Am Acad Dermatol 2013;68(3):425-32. 